\title{
Inhibition of human chondrosarcoma cell growth via apoptosis by peroxisome proliferator-activated receptor- $\gamma$
}

\author{
K Nishida*,', T Furumatsu', I Takada', A Kawai', A Yoshida', T Kunisada' and H Inoue' \\ 'Department of Orthopaedic Surgery, Faculty of Medicine, Okayama University Medical School, 2-5-I Shikata-cho, Okayama City, Okayama 700-8558, Japan
}

A rare immunohistochemical study using 28 surgical sections of human chondrosarcoma revealed that $67.9 \%$ of tumour cells had weak (10-40\%) or strong (>40\%) positive immunoreaction for peroxisome proliferator-activated receptor- $\gamma$. The expression of peroxisome proliferator-activated receptor- $\gamma$ mRNA and protein in human chondrosarcoma cell line OUMS-27 was also determined by reverse transcription-polymerase chain reaction and immunocytochemistry, respectively. Furthermore, the effects of peroxisome proliferator-activated receptor- $\gamma$ ligands on cell proliferation and survival were investigated in OUMS-27 cells. Pioglitazone, a selective ligand for peroxisome proliferator-activated receptor- $\gamma$, and $15-$ deoxy- $\Delta^{12,14}$-prostaglandin $J_{2}(15 d-$ $\left.P G\right|_{2}$ ), a putative endogenous ligand for peroxisome proliferator-activated receptor- $\gamma$, inhibited the proliferation of OUMS-27 cells in a dose-dependent manner. The mechanism of cytotoxic effects of $15 \mathrm{~d}-\mathrm{PG} \mathrm{J}_{2}$ was via apoptosis as shown by DNA fragmentation using TUNEL stain and DNA ladder formation, and by ultrastructural analysis using transmission electron microscopy. Flow-cytometric analysis using annexin-V-fluorescein and propidium iodide detected the early change of apoptosis, as well as necrosis of OUMS-27 cells at $4 \mathrm{~h}$ after co-incubation with $15 \mathrm{~d}-\mathrm{PG} \mathrm{J}_{2}$. These results suggest that peroxisome proliferator-activated receptor- $\gamma$ may play a significant role in the pathogenesis of chondrosarcoma, and peroxisome proliferatoractivated receptor- $\gamma$ ligands, especially $|5 \mathrm{~d}-\mathrm{PG}|_{2}$, may be of therapeutic value in the treatment of human chondrosarcoma. British Journal of Cancer (2002) 86, 1303 - 1309. DOI: 10.1038/sj/bjc/660024I www.bjcancer.com

(c) 2002 Cancer Research UK

Keywords: chondrosarcoma; apoptosis; PPAR $;$; $15 \mathrm{~d}-\mathrm{PG} \mathrm{J}_{2}$

Peroxisome proliferator-activated receptors (PPARs) are members of the nuclear receptor superfamily of ligand-activated transcription factors. To date, three mammalian PPAR subtypes have been isolated, and termed $\operatorname{PPAR} \alpha, \operatorname{PPAR} \delta$ and $\operatorname{PPAR} \gamma$, which heterodimerise with the retinoid $\mathrm{X}$ receptors (Kliewer et al, 1992). PPAR $\alpha$ is predominantly expressed in the liver, and studies have focused on its role in lipid metabolism (Latruffe and Vamecq, 2000). $\operatorname{PPAR} \delta$ is ubiquitously expressed, but its function is not well understood. Although PPAR $\gamma$ was first found to be expressed at high levels in adipose tissue, and functions as a critical regulator of adipocyte differentiation and fat metabolism (Chawla et al, 1994), the expression of PPAR $\gamma$ is not restricted to the cells of the adipocytic lineage, and has been demonstrated in many other human cell types including chondrocytes (Bordji et al, 2000).

Induction of differentiation and apoptosis in cancer cells by ligands of PPAR $\gamma$ is a novel therapeutic approach against malignant tumours. Recent studies reported that 15 -deoxy- $\Delta^{12,14}$-prostaglandin $\mathrm{J}_{2}\left(15 \mathrm{~d}-\mathrm{PG} \mathrm{J}_{2}\right)$, the most potent endogenous ligand for PPAR $\gamma$, and the synthetic PPAR $\gamma$ ligand thiazolidinedione (TZD) can induce terminal differentiation and growth inhibition of human liposarcoma (Tontonoz et al, 1997), breast (Elstner et al, 1998; Yee et al, 1999), prostate (Kubota et al, 1998), colon (Sarraf et al, 1998; Kitamura et al, 1999), gastric (Takahashi et al, 1999; Sato et al, 2000), lung (Chang and Szabo, 2000; Tsubouchi et al, 2000), and pancreas (Motomura et al, 2000; Elnemr et al, 2000) cancer cells, as well as hepatoma cells

*Correspondence: K Nishida; E-mail: knishida@md.okayama-u.ac.jp Received 5 November 200I; revised 14 February 2002; accepted 15 February 2002
(Koga et al, 2001) in vitro and in vivo. The in vivo induction of histological and biochemical differentiation of liposarcomas by clinical trial of troglitazone administration was reported by Demetri et al (1999). Among these patients the immunohistochemical expression of Ki-67, a marker of cell proliferation was markedly reduced. The authors of a similar in vivo trial have suggested the clinical efficacy of troglitazone in prostate cancer (Mueller et al, 2000). Although the precise mechanism is still unknown, the interference in tumour cell growth by PPAR $\gamma$ ligands may have a favourable clinical effect.

Chondrosarcoma is a relatively rare malignant bone tumour accounting for only $3-6 \%$ of primary bone tumours (Mirra, 1989; Schajowics, 1994; Unni, 1996). The histologic grade of chondrosarcoma which indicates the differentiation status of tumour cells, is one of the most important factors for the prognosis of the disease (Evans et al, 1977). The surgical treatment of chondrosarcoma with adequate marginal resection is effective for low-grade chondrosarcoma with better clinical outcomes (Ozaki et al, 1996). However, for high-grade chondrosarcoma, the prognosis is poor even after adequate surgery (Sheth et al, 1996), the efficacy of systemic chemotherapy or irradiation is still unclear. Thus, the development of clinically useful agents which inhibit cell growth and induce cell death may be useful in the treatment of chondrosarcoma.

In the current study, the first of its kind, the authors examined the expression of PPAR $\gamma$ both in surgically resected sections of human chondrosarcoma and OUMS-27 cells (Kunisada et al, 1998), a novel cell line established from a grade III human chondrosarcoma of a 65-year-old male. The examination of the effects of PPAR $\gamma$ ligands on OUMS-27 cells demonstrated that PPAR $\gamma$ ligands inhibited cell proliferation in a dose-dependent manner, and induced apoptosis of OUMS-27. The findings of the current 
study might contribute to the development of novel therapies for human chondrosarcoma.

\section{MATERIALS AND METHODS}

\section{Immunohistochemistry on patient specimens and semiquantitative analysis}

Immunohistochemistry was performed as previously described (Nishida et al, 2001) on formalin-fixed, paraffin-embedded tissues of human chondrosarcoma surgically resected from 28 patients. Briefly, sections were treated by polyclonal anti-human PPAR antibody (Affinity BioReagents, Inc, Golden, CO, USA) diluted into $10 \mu \mathrm{g} \mathrm{ml}^{-1}$ with PBS containing $0.1 \% \mathrm{NaN}_{3}$ and $0.1 \%$ bovine serum albumin (British Biocell International Co, UK). After incubation for $30 \mathrm{~min}$ at room temperature with $7.5 \mu \mathrm{g} \mathrm{ml}^{-1}$ of biotinylated goat anti-rabbit IgG (Vector Laboratories Inc, CA, USA), tissues were then treated by $A B C$ method for $30 \mathrm{~min}$, visualised with diaminobenzidine (DAB) (Sigma) in $\mathrm{H}_{2} \mathrm{O}_{2}(0.01 \%)$ for $5 \mathrm{~min}$, and counterstained with methyl-green. Negative control was obtained in the same fashion but excluding the primary antibody. They were then examined under a light microscope.

Each specimen showed pathologically different grades of chondrosarcoma; grade I $(n=20)$, grade II $(n=6)$ and grade III $(n=2)$. For the semiquantitative analysis of $\operatorname{PAAR} \gamma$ positive tumour cells in the human tissue, the amount of the staining was evaluated in each of the three grades of chondrosarcoma.

\section{Cells and cell culture}

The human chondrosarcoma cell line OUMS-27 was a generous gift from Dr Masayosi Namba (Okayama University Medical School, Japan). OUMS-27 is a cell line established from grade III chondrosarcoma of a 65-year-old patient. The cells were cultured in Dulbecco's modified Eagle's medium (DMEM) containing $450 \mathrm{mg} \mathrm{dl}^{-1}$ glucose, supplemented with $10 \%$ foetal bovine serum (FBS) (Life Technologies, Rockville, MD, USA), $100 \mathrm{U} \mathrm{ml}^{-1}$ penicillin, and $100 \mu \mathrm{g} \mathrm{ml}^{-1}$ streptomycin (Life Technologies). Cells were incubated at $37^{\circ} \mathrm{C}$ in a humidified atmosphere of $5 \% \mathrm{CO}_{2}$ in air. Cells were sub-cultured at a split ratio of $1: 3$ every $7-10$ days with $0.1 \%$ trypsin (Life Technologies), $5 \mathrm{~mm}$ EDTA solution. The medium was regularly changed twice a week.

\section{RNA extraction and RT - PCR}

Total cellular RNA was extracted from confluent cells using the RNA plus kit (Bioprobe System, Montreuil, France). For reverse transcriptase-polymerase chain reaction (RT-PCR), RNA samples $(5 \mu \mathrm{g})$ were reverse-transcribed to cDNA using reverse transcriptase (ReverTra Ace, Toyobo Co. Ltd., Osaka, Japan) and subsequently amplified by PCR using as a sense primer, $5^{\prime}$-TCTCTCCGTAATGGAAGACC$3^{\prime}$ and an antisense primer, $5^{\prime}$-GCATTATGAGAC-ATCCCCAC- $3^{\prime}$ as previously reported (Takahashi et al, 1999). Human adult normal adipose total RNA was purchased from BioChain Institute, Inc, CA, USA (Catalogue Number 061005). Samples were reverse-transcribed to cDNA and used for the positive control of PPAR $\gamma$ mRNA expression. The reaction conditions were as follows: initial denaturation at $94^{\circ} \mathrm{C}$ for $2 \mathrm{~min}$ and 30 cycles of amplification $\left(30 \mathrm{~s}\right.$ at $94^{\circ} \mathrm{C}, 30 \mathrm{~s}$ at $58^{\circ} \mathrm{C}$, and $40 \mathrm{~s}$ at $72^{\circ} \mathrm{C}$ ) in an automated thermal cycler (Perkin Elmer Applied Biosystems, Foster, CA, USA), followed by a final extension step of $4 \mathrm{~min}$ at $72^{\circ} \mathrm{C}$. PCR products were run on $1 \%$ agarose gels.

\section{Immunocytochemistry}

The expression of $\operatorname{PPAR} \gamma$ at the protein level was determined by immunocytochemistry. Briefly, cells were cultured at a density of $1 \times 10^{5}$ cells per well in 6 -well plastic culture dishes (Primaria, France), and fixed in $2 \%$ paraformaldehyde in $0.1 \mathrm{M}$ phosphate buffered saline (PBS, $\mathrm{pH}$ 7.4) for $30 \mathrm{~min}$ at room temperature, washed in PBS. After permeabilisation in $0.1 \%$ Triton X-100 (Nacalai Tesque Inc., Kyoto, Japan) for $5 \mathrm{~min}$ at room temperature, nonspecific staining was blocked by $10 \%$ normal goat serum (Vector Laboratories, Burlingame, CA, USA). Immunocytochemistry for $\operatorname{PPAR} \gamma$ was performed in the same fashion as described above.

\section{Reagents for activation of PPAR $\gamma$}

Pioglitazone, a selective ligand for $\operatorname{PPAR} \gamma$, was kindly provided from Takeda Chemical Industries (Osaka, Japan). 15d-PGJ 2 , a potent natural ligand for $\operatorname{PPAR} \gamma$, was purchased (from Biomol Research Laboratories, Inc, MI, USA). These PPAR $\gamma$ ligands were dissolved in dimethyl sulphoxide (DMSO) with a final concentration of $0.1 \%$ DMSO in the culture medium.

\section{Cell proliferation and viability assay}

Cells were seeded at $1 \times 10^{4}$ cells per well in a 96-well culture plate or 8-well culture plate (Coster, Cambridge, MA, USA) in $100 \mu \mathrm{l}$ $10 \%$ FCS-DMEM and incubated for $24 \mathrm{~h}$ at $27^{\circ} \mathrm{C}$. For the activation of PPAR $\gamma$, cells were treated with increasing concentrations of pioglitazone and $15 \mathrm{~d}-\mathrm{PGJ}_{2}$ for $24 \mathrm{~h}$.

To know the effects of pioglitazone and $15 \mathrm{~d}-\mathrm{PGJ}_{2}$ on the proliferation grade of cell growth, an immunocytochemical study was performed in the same manner as described above on the cells cultured in 8-well culture plate, using monoclonal anti-Ki-67 antibody (Zymed Laboratories Inc, CA, USA) as a primary antibody and anti-mouse IgG (Vector Laboratories Inc, CA, USA) diluted to a final concentration of $10 \mu \mathrm{g} \mathrm{ml}^{-1}$ as a secondary antibody. PBS without primary antibody was used as the negative control. Semi-quantitative analysis on the Ki-67-immunostained cells were performed by counting the positive cell number per total cells in four fields at a magnification of $\times 200$ under light microscopy.

Cell viability in a 96-well culture plate was evaluated using the colorimetric MTT assay (Chemicon International, Inc, Temecula, CA, USA) according to the manufacturer's instructions. Quantitation was then conducted using Model 550 microplate reader (BioRad, Hercules, CA, USA) at 595-655 nm. Results of optimal density units per $1 \times 10^{4}$ adherent cells were expressed as \% MTT.

\section{DNA fragmentation analysis}

Cells were cultured for $24 \mathrm{~h}$ in the presence or absence of $15 \mathrm{~d}-\mathrm{PGJ}_{2}$ $\left(10 \mu \mathrm{g} \mathrm{ml}^{-1}\right)$ at a density of $1 \times 10^{5}$ cells per well in 6-well plastic culture dishes. Cells were fixed in $2 \%$ paraformaldehyde in PBS ( $30 \mathrm{~min}$ at room temperature). Cells were then doubly stained by nick end-labelling method to detect the fragmented DNA, and Hoechst 33258 (Wako, Osaka, Japan) to observe the nuclear morphology of the cells. Briefly, cells were first incubated with TdT reaction solution ( $2 \mu \mathrm{g}$ terminal deoxynucleotidyle transferase (TdT) and $5 \mu \mathrm{g}$ FITC-conjugated deoxyuridine triphosphate (dUTP) in $1200 \mu \mathrm{l}$ TdT buffer). The cells were then stained by Hoechst 33258 $\left(10 \mu \mathrm{g} \mathrm{ml}^{-1}\right)$ for $5 \mathrm{~min}$ at room temperature. After thorough washing in PBS, cells were observed by fluorescent microscopy.

The Apoptotic DNA Ladder Kit (Roche Diagnostics GmbH, Mannheim, Germany) was used for DNA ladder assay according to the manufacturer's instructions. Briefly, cells were cultured in serum-free DMEM at a density of $2.5 \times 10^{6}$ cells in $75 \mathrm{~mm}^{2}$ tissue culture flask (Greiner, Frickenhawen, Germany), stimulated with $15 \mathrm{~d}-\mathrm{PGJ}_{2}\left(10 \mu \mathrm{g} \mathrm{ml}^{-1}\right)$ for $24 \mathrm{~h}$. Cells were homogenised in lysis buffer, and DNA was isolated. The samples were separated on a $2 \%$ agarose gel and stained with $10 \mu \mathrm{g} \mathrm{ml}^{-1}$ ethidium bromide.

\section{FACS analysis using annexin-V-FITC}

The expression of phosphatidylserine on the outer leaflet of apoptotic cell membranes was examined by fluorescence-activated cell 
sorter (FACS) analysis. Annexin-V-Fluos Staining Kit (Roche Diagnostics $\mathrm{GmbH}$, Mannheim, Germany) was used according to the manufacturer's instructions to stain the apoptotic cells and to differentiate them from necrotic cells. Briefly, cells were seeded at a density of $1 \times 10^{6}$ cells on $25 \mathrm{~cm}^{2}$ tissue culture flask (Becton Dickinson, Planklin Lakes, NJ, USA) in serum-free DMEM were pretreated with $15 \mathrm{~d}-\mathrm{PGJ}_{2}\left(10 \mu \mathrm{g} \mathrm{ml}^{-1}\right)$ for 4,8 and $24 \mathrm{~h}$, washed with PBS and centrifuged at $200 \mathrm{~g}$ for $5 \mathrm{~min}$. Cell pellets were then re-suspended in $100 \mu \mathrm{l}$ of $2 \%$ Annexin-V-fluorescein labelling reagent in Hepes buffer containing $2 \%$ propidium iodide (PI) and incubated for $15 \mathrm{~min}$ at 15 to $25^{\circ} \mathrm{C}$. After washing extensively, stained cells were analysed using a FACScan (Becton Dickinson, San Jose, CA, USA) and 1000 events in the live gate were recorded (a $515 \mathrm{~nm}$ bandpass filter for fluorescein and a filter $>600 \mathrm{~nm}$ for PI detection).

\section{Transmission electron microscopy}

Ultrastructural appearances of apoptotic cells were confirmed by electron microscopic study. Cells were first incubated with or with-

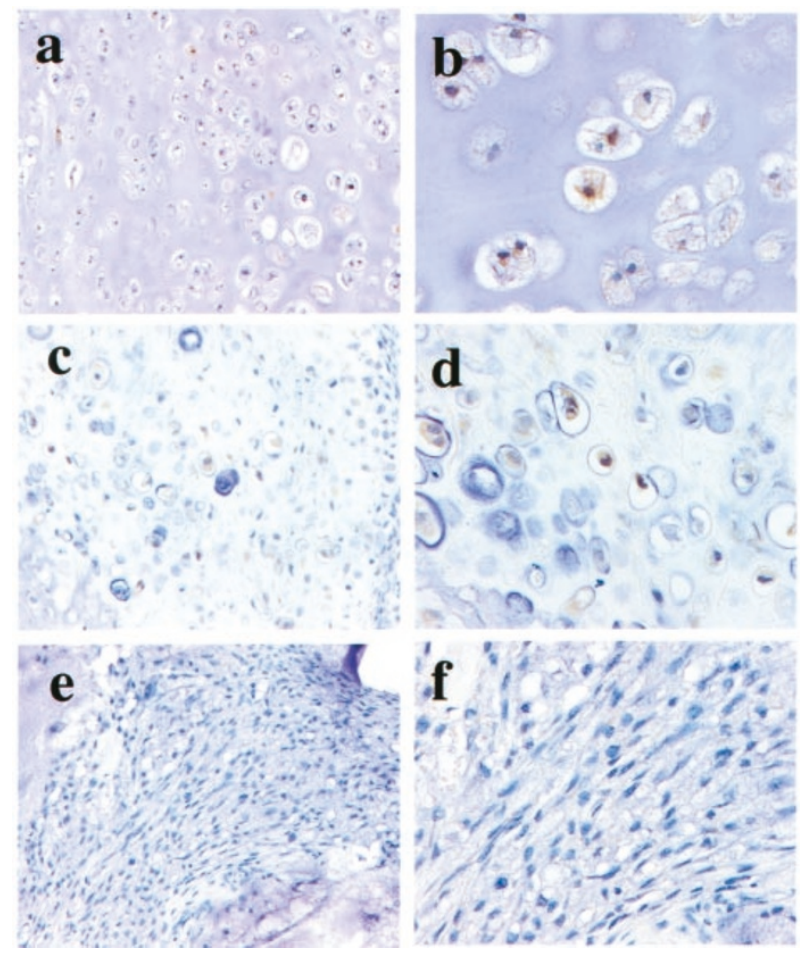

Figure I Expression of PPAR $\gamma$ protein of the cells in grade I $(\mathbf{A}, \mathbf{B})$ and grade $\|(\mathbf{C , D})$ areas within chondrosarcoma specimens from patients. Note there are few positive immuno-reactions in the cells in the grade III areas $(\mathbf{E}, \mathbf{F})$. Magnification; A,C,E $50 \times, \mathbf{B}, \mathbf{D}, \mathbf{F} \mid 00 \times$.

Table I Summary of immunohistochemical study for PPAR $\gamma$ in human chondrosarcoma tissues

\begin{tabular}{lccc}
\hline & \multicolumn{3}{c}{ Pathological grade of chondrosarcoma } \\
\cline { 2 - 4 } & $\mathbf{I}(\mathbf{n}=\mathbf{2 0})$ & II $(\boldsymbol{n}=\mathbf{6})$ & III $(\boldsymbol{n}=\mathbf{2})$ \\
\hline None & 7 & 1 & 1 \\
Weak & 8 & 2 & 1 \\
Strong & 5 & 3 & 0 \\
\hline
\end{tabular}

Positive cell ratios labelled by polyclonal antibodies for PPAR $\gamma$ were expressed: None; $<10 \%$, Weak; $10-40 \%$, Strong; $>40 \%$ of cells positive. out $15 \mathrm{~d}-\mathrm{PGJ}_{2}\left(10 \mu \mathrm{g} \mathrm{ml}^{-1}\right)$ for $8 \mathrm{~h}$. Then cells were scraped, pelletised, rinsed with $\mathrm{PBS}$, and then fixed in $1 \%$ glutaraldehyde in PBS ( $\mathrm{pH} 7.4$ ) overnight at $4^{\circ} \mathrm{C}$. After rinsing in PBS three times, cell pellets were dehydrated by a graded series of ethanol, and finally embedded in hydrophilic resin (LR-White). Semi-thin sections were first stained by toluidine blue and examined by light microscopy. Adjacent ultra-thin sections were then contrasted with aquenous uranyle acetate and lead citrate, and examined by a transmission electron microscope (TEM) (type 7100, Hitachi, Tokyo).

\section{Statistical analysis}

The results are expressed as mean \pm s.e.m. Statistical analysis was performed by one way analysis of variance and subsequent Fisher's LSD test. $P<0.05$ was considered statistically significant.

\section{RESULTS}

\section{Expression of PPAR $\gamma$ in human chondrosarcoma and OUMS-27 cells}

Immunohistochemical examination revealed that human chondrosarcoma cells frequently express PPAR $\gamma$ at protein level (Figure 1). In the nuclei of differentiated chondrocytes showed strong positive reaction for PPAR $\gamma$, but not in the well differentiated hypertrophic chondrocytes nor undifferentiated mesenchymal cells. The results of the semiquantitative analysis for $\operatorname{PPAR} \gamma$-positive cells were summarised in Table 1 . The positivity (the cutoff positivity of $10 \%$ ) of chondrosarcoma cells were $65.0 \%$ in grade I, $83.3 \%$ in grade II, and $50.0 \%$ in grade III, and overall positivity was $67.9 \%$. RT-PCR analysis was done to examine the expression of PPAR $\gamma$ mRNA in OUMS-27 cells. The predicted band size (474 bp) of PPAR $\gamma$ mRNA was clearly detected in OUMS-27 cells (Figure 2A). Immunocytochemistry using polyclonal anti-human PPAR $\gamma$ antibody showed the nuclear localisation of PPAR $\gamma$ in OUMS-27 cells. Negative controls treated with non-immune serum or without primary antibodies showed no positive reaction (Figure $2 \mathrm{~B}$ a,b). These data indicated that PPAR $\gamma$ is frequently expressed both in primary chondrosarcomas as well as cancer cell line OUMS-27.

A

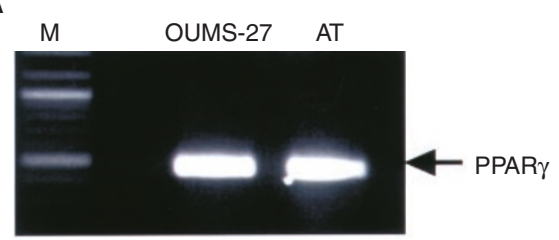

B

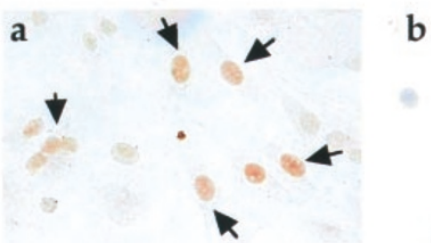

Figure 2 Expression of PPAR $\gamma$ in OUMS-27 cells. (A) Reverse transcription of total RNA into CDNA and RT - PCR was performed using specific primers for PPAR $\gamma$. PPAR $\gamma$ was expressed at the mRNA level (474 bp) in OUMS-27 cells (arrow) as well as human adult normal adipose tissue. M: molecular control, AT: adipose tissue. (B) Immunocytochemical analysis of PPAR $\gamma$ in OUMS-27 cells was performed using polyclonal anti-PPAR $\gamma$ antibodies. a: Nuclear localisation of PPAR $\gamma$ protein (arrow heads), b: negative control. 
A

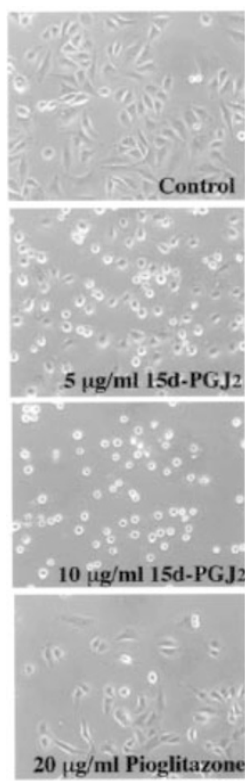

\section{B}

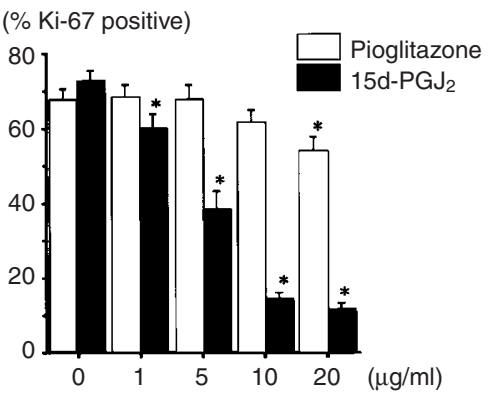

\section{C} (\% control)

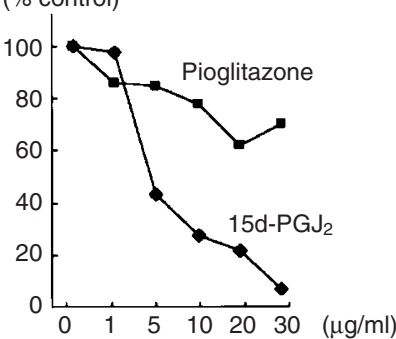

Figure 3 Effect of PPAR $\gamma$ ligands on OUMS-27 cell morphology and proliferation. OUMS-27 cells were cultured and treated with various concentrations of pioglitazone, I5d-PG 2 or vehicle $(0.1 \%$ DMS) for $24 \mathrm{~h}$. (A) Under the phase contrast microscopy, cells showed relatively round shapes with loss of cell volume and detached from the dishes when treated with doses of $\left|5 \mathrm{~d}-\mathrm{PG} \mathrm{J}_{2} 5 \mu \mathrm{g} \mathrm{m}\right|^{-1}$ or higher. High dose $|5 \mathrm{~d}-\mathrm{PG}|_{2}$ treatment (over $10 \mu \mathrm{g} \mathrm{ml}^{-1}$ ) caused cell detachment only $2 \mathrm{~h}$ after co-incubation. Pioglitazone treatment induced fewer morphological changes. (B) To identify the proliferative grade of cell growth, Ki-67-positive cell index was determined by counting the positive cells per total cells in four fields. Data are expressed as mean \pm s.e.m. of four fields. $* P<0.01$, when compared with vehicle only (ligands dose $0 \mu \mathrm{g} \mathrm{ml}^{-1}$ ). (C) Cell viability was determined by MTT assay. Although both PPAR $\gamma$ ligands inhibited cell growth in a dose dependent manner, the effects were more remarkable in $15 \mathrm{~d}-\left.\mathrm{PG}\right|_{2}$.

Inhibition of OUMS-27 cell proliferation by PPAR $\gamma$ ligands

After the treatment with two different kinds of PPAR $\gamma$ ligands, the morphologic features of OUMS-27 cells were observed under phase contrast microscopy. Cells treated with vehicle only (0.1\% DMSO) had a polygonal shape and adhered to the plastic surface. Cells treated with $15 \mathrm{~d}-\mathrm{PGJ}_{2}$ at $1 \mu \mathrm{g} \mathrm{ml}^{-1}$ appeared less active, but still had a polygonal appearance. When cells were treated with doses of $15 \mathrm{~d}-\mathrm{PGJ}_{2}$ at $5 \mu \mathrm{g} \mathrm{ml}^{-1}$ or higher, they showed relatively round shapes with cell shrinkage and apoptotic body-like structure and some cells could no longer adhere to the dish. The treatment with pioglitazone did not induce so much morphological change when compared with $15 \mathrm{~d}-\mathrm{PGJ}_{2}$ treatment (Figure $3 \mathrm{~A}$ ). The results of immunostain for Ki-67 and MTT assay indicated that both pioglitazone and $15 \mathrm{~d}-\mathrm{PGJ}_{2}$ for $24 \mathrm{~h}$ inhibited the cell growth and reduced cell viability in a dose-dependent manner (Figure 3B,C). Interestingly, cell growth was markedly reduced when treated with $15 \mathrm{~d}-\mathrm{PG} \mathrm{J}_{2}$.

\section{Induction of apoptosis of OUMS-27 cells by PPAR $\gamma$ ligands}

In order to confirm the apoptosis induced by PPAR $\gamma$ activation, DNA fragmentation was analysed both biochemically and morphologically. Hoechst staining showed condensed DNA chromatin morphology in OUMS-27 cells treated by $15 \mathrm{~d}-\mathrm{PGJ} \mathrm{J}_{2}$ for $24 \mathrm{~h}$. The appearance of these cells was consistent with that of the cells positive for TUNEL staining which indicate DNA fragmentation (Figure 4A). Treatment of OUMS-27 cells with $15 \mathrm{~d}-\mathrm{PGJ}_{2}$ $\left(10 \mu \mathrm{g} \mathrm{ml}^{-1}\right)$ for $24 \mathrm{~h}$ induced DNA ladder formation (Figure 4B). Semi-thin sections of LR-White embedded cells stained by toluidine blue showed a large number of OUMS-27 cells treated with $15 \mathrm{~d}-\mathrm{PGJ}_{2}$ with characteristic apoptotic features; cell shrinkage and nuclear condensation (Figure 5A,B). TEM study revealed that untreated OUMS-27 cells have extensive rough-surfaced endoplasmic reticulum, thickened mitochondria and numerous cytoplasmic vesicles (Figure 5C). In contrast, when treated with $15 \mathrm{~d}-\mathrm{PGJ}_{2}$, the sections contained many apoptotic cells with condensed chromatin, many vacuoles in the cytoplasm and membrane budding (Figure 5D). FACS analysis indicated the population of apoptotic cells with $\mathrm{PS}$ at the outer membrane of the cells (annexin-V positive, PI
A
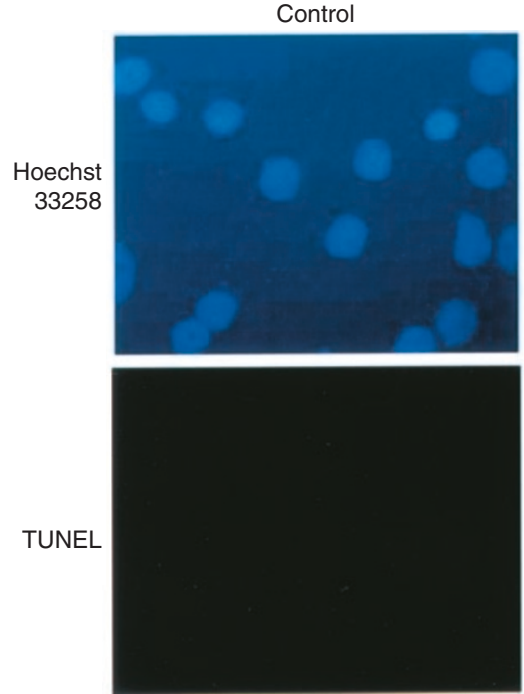
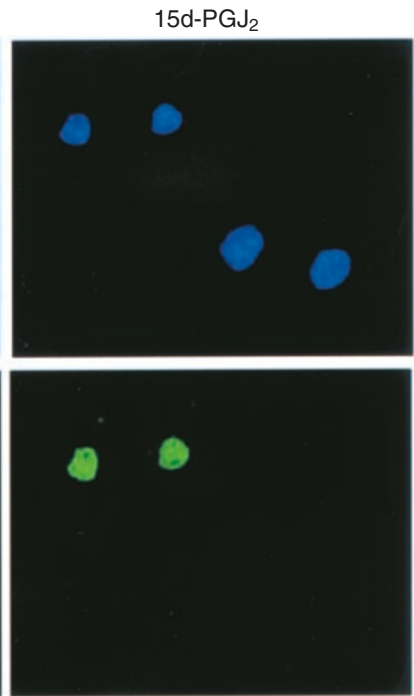

B

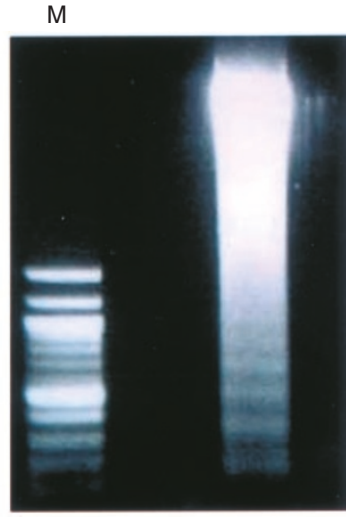

Figure 4 Induction of apoptosis by $15 \mathrm{~d}-\left.\mathrm{PG}\right|_{2}$ in OUMS-27. (A) OUMS-27 cells were incubated with or without I5d-PG $\left.\right|_{2}\left(10 \mu \mathrm{g} \mathrm{ml}{ }^{-1}\right.$ ) for $24 \mathrm{~h}$. Cells were doubly stained by Hoechst 33258 and simultaneously analysed by TUNEL stain, and observed by fluorescent microscopy. The cells with morphologically condensed nucleus were TUNEL positive, indicating the existence of fragmented DNA. (B) DNA was isolated TUNEL positive, indicating the existence of fragmented DNA. (B) DNA was isolated from the cells after co-incubation with I5d-PG $]_{2}\left(I 0 \mu \mathrm{g} \mathrm{ml}^{-1}\right)$ for 24 h. A clear DNA-ladder formation was obtained after electrophoresis on a $2 \%$ agarose gel. M: marker. 
negative) was approximately 53.9 and 67.6\%, whereas those of necrotic cells (annexin-V positive, PI positive) were approximately 22.3 and $21.4 \%$ at 4 and $24 \mathrm{~h}$, respectively, after treatment with $15 \mathrm{~d}-\mathrm{PGJ}_{2}$ (Figure 6).

\section{DISCUSSION}

There are few human chondrosarcoma cell lines with chondrocytic properties, OUMS-27 is a novel cell line established from grade III human chondrosarcoma by Kunisada et al (1998). OUMS-27 cells

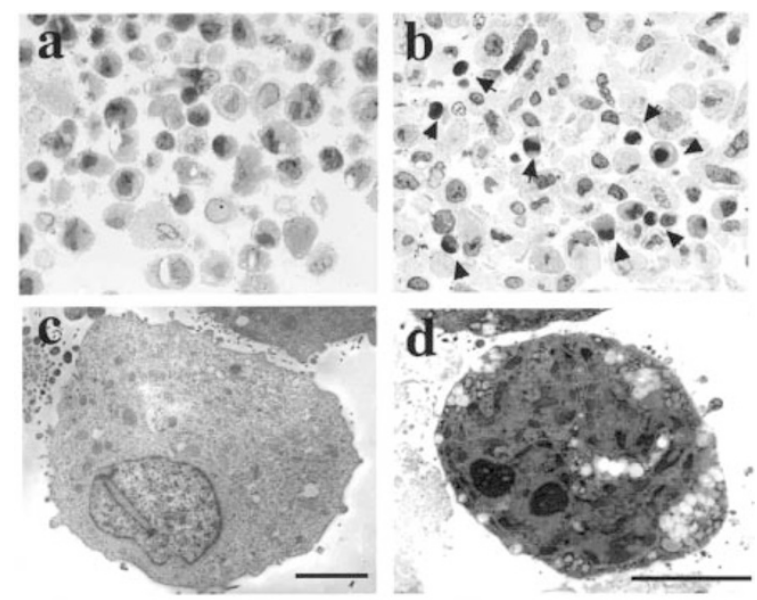

Figure 5 Cell morphology after incubation with or without $15 \mathrm{~d}-\mathrm{PG}_{2}$. The cells were treated by $10 \mu \mathrm{g} \mathrm{ml}^{-2}$ of $15 \mathrm{~d}-\mathrm{PG}_{2}$ for $8 \mathrm{~h}$, and the cell pellet was embedded in hydrophilic resin. Semi-thin sections stained by toluidine blue show cell shrinkage and nuclear condensation (arrow heads) (B). TEM analysis of ultra-thin section after metal stain revealed typical apoptotic feature. Cells were small, and contained pyknotic nuclei, electron-dense granules and many vacuoles (D). (A and $\mathbf{C}$ ) Control specimens without stimulation by $15 \mathrm{~d}-\left.\mathrm{PG}\right|_{2}$. Bar $=5 \mu \mathrm{m}$. do not show contact inhibition after reaching confluence and grow rapidly in multiple layers. The cells express proteoglycan, as well as type I, II, III, IX and XI collagen after 120 passages, showing stable maintenance of the differentiated chondroctic properties. The transplantation of OUMS-27 cells into athymic mice resulted in formation of grade II (of III) chondrosarcoma at injected site (Kunisada et al, 1998). Thus, the OUMS-27 cell line appears to be a useful model for studies for chondrocyte function as well as the aetiology and treatment of human chondrosarcoma.

Recent studies strongly suggest the attractive concept that PPAR $\gamma$ ligands might be useful agents in the induction of cell differentiation or apoptosis in cancer cells. In the current study, the authors demonstrated for the first time that PPAR $\gamma$ is expressed in both surgically resected human chondrosarcoma and OUMS-27 cells. The frequent expression of PPAR $\gamma$ in chondrosarcoma cells indicated the involvement of PPAR $\gamma$ in the pathogenesis of chondrosarcoma and suggested the possible inhibitory effect on cancer cell growth and proliferation by $\operatorname{PPAR} \gamma$ activation.

TUNEL staining, DNA ladder formation and TEM revealed that the type of cell death induced by $15 \mathrm{~d}-\mathrm{PGJ}_{2}$ was apoptosis. Interestingly, early apoptotic change, and the translocation of phosphatidylserine on the outer leaflet of the cell membrane were demonstrated only $4 \mathrm{~h}$ after co-incubation with $15 \mathrm{~d}-\mathrm{PGJ}_{2}$. To date, the exact intracellular signaling pathways leading to apoptotic cell death following specific activation of $\operatorname{PPAR} \gamma$ is not fully understood, several factors have been suggested to be involved in $\operatorname{PPAR} \gamma$ ligand-induced apoptosis. The activation and actin of caspases is believed to be a pivotal step in the mechanism of apoptosis. In JEG3 choriocarcinoma cells, $15 \mathrm{~d}-\mathrm{PGJ}_{2}$-induced apoptosis measured by a decline in MTT activity was significantly inhibited by the caspase inhibitor ZVAD-fmk, but the inhibitory effect was up to $50 \%$ (Keelan et al, 1999). Previous reports suggested the involvement of a caspase-3-independent mechanism in $15 \mathrm{~d}-\mathrm{PGJ}_{2}-$ induced loss of MTT activity (Miyashita et al, 1998). We found that the inhibitors for caspase-1, 3, 8, 9, and ZVAD-fmk $(2 \mu \mathrm{M})$ did not have significant effect on the $15 \mathrm{~d}-\mathrm{PGJ} \mathrm{J}_{2}$-induced loss of MTT activity in OUMS-27 (data not shown). It is speculated that
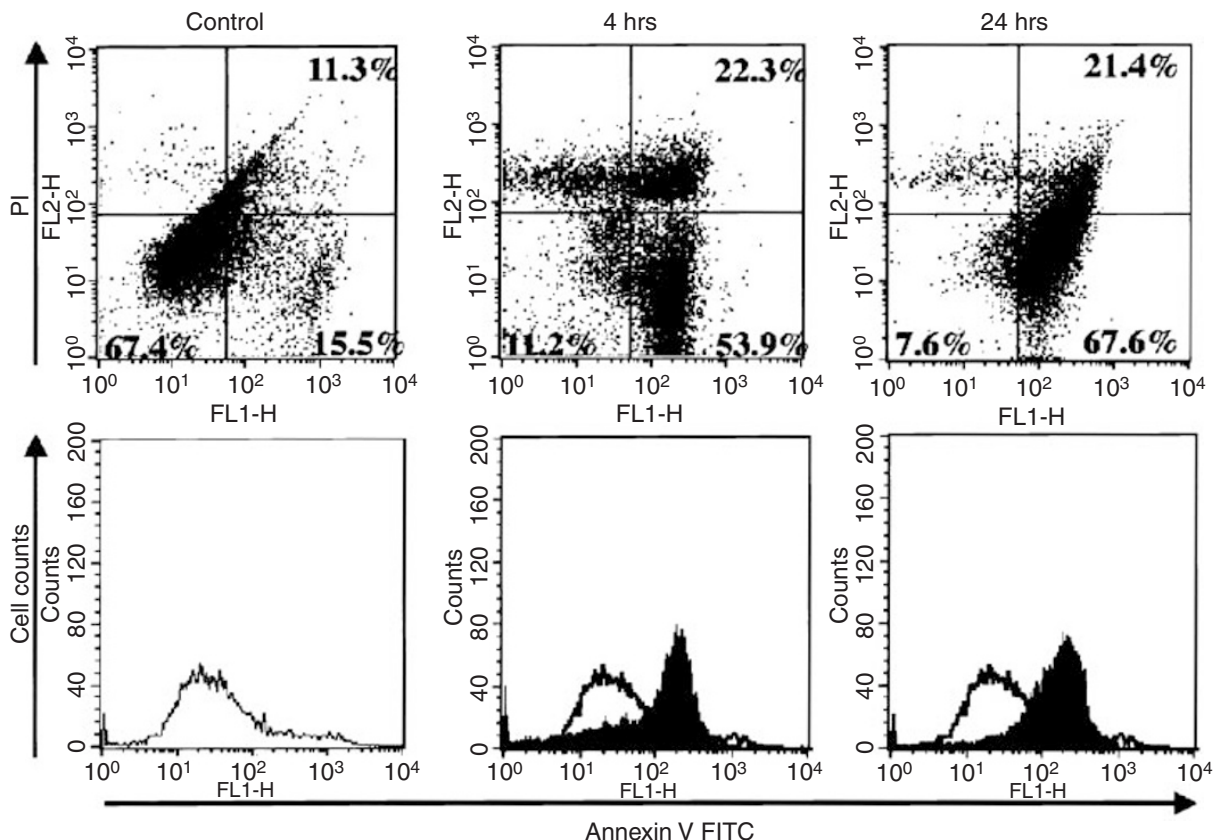

Figure 6 Effects of I $5 \mathrm{~d}-\mathrm{PG} \mathrm{J}_{2}$ on OUMS-27 cells analysed by flow cytometry. The cells were incubated with or without I5d-PGJ $\left(\left.10 \mu \mathrm{g} \mathrm{ml}\right|^{-1}\right)$ for $4,24 \mathrm{~h}$ and then analysed by flow cytometry. Cells were labelled with annexin-V-FITC and propidium iodide (PI) to distinguish apoptotic and/or necrotic cells from normal cells. Four hours incubation with $15 \mathrm{~d}-\left.\mathrm{PG}\right|_{2}$ caused early apoptotic change (annexin- $\mathrm{V}$ positive, $\mathrm{Pl}$ negative) in $53.9 \%$ of the cells. The necrotic cells (annexin- $V$ positive, $\mathrm{Pl}$ positive) were also detected in $22.3 \%$. The population of apoptotic cells increased to $67.6 \%$ at $24 \mathrm{~h}$ after treatment with I5 $\mathrm{d}-\mathrm{PG} \mathrm{J}_{2}$. 
the caspase-independent mechanism might be partly involved in the $15 \mathrm{~d}-\mathrm{PGJ}_{2}$-induced apoptosis in OUMS-27.

We also demonstrated that the ligands of $\operatorname{PPAR} \gamma$, both pioglitazone and 15d-PGJ ${ }_{2}$, inhibited cell growth and induced cell death in a dose dependent manner. The $15 \mathrm{~d}-\mathrm{PGJ}_{2}$ had more noticeable effects on OUMS-27 cell growth than pioglitazone. Thus, it is still unclear whether the effects of ligands on OUMS-27 cells were strictly due to PPAR $\gamma$ activation. The detailed analysis of the effects of ligands on the cells which do not express PPAR $\gamma$ should provide important clues to understand this phenomenon. Okura et al (2000) demonstrated that troglitazone can induce vascular smooth muscle cell apoptosis via the tumour suppressor p53, but not by $\operatorname{PPAR} \gamma$ activation. We have previously shown by functional analysis of separated alleles in yeast (FASAY) assay that the p53-gene status of OUMS-27 is a mutant-type (Kunisada et al, 1998). The mutant p53 is known to inhibit the tumour-suppressor activity of wildtype p53 protein (Levine, 1997). In this line, mutant status of p53 might be involved in the pathway of the inhibition of OUMS-27 cell growth by PPAR $\gamma$ ligands. Other studies indicated that inhibition of transcriptional activation by nuclear receptors can be effected by competition for limited amounts of co-activators such as cAMP response element binding protein (CREB)-binding protein (CBP)/p300, Src-1 or TIF1 (Kamei et al, 1996; Göttlicher et al, 1998; Sheppard et al, 1998). It may be speculated that the difference in the recruitment of co-activators might influence the effectiveness of each ligand.

It has been shown that PPAR $\gamma$ has regulatory functions in the cell cycle by altering cell growth (Motomura et al, 2000; Okura

\section{REFERENCES}

Bordji K, Grillasca JP, Gouze JN, Magdalou J, Schohn H, Keller JM, Bianchi A, Dauca M, Netter P, Terlain B (2000) Evidence for the presence of peroxisome proliferator-activated receptor (PPAR) alpha and gamma and retinoid $\mathrm{Z}$ receptor in cartilage. PPAR $\gamma$ activation modulates the effects of interleukin-1beta on rat chondrocytes. J Biol Chem 275: $12243-12250$

Chang TH, Szabo E (2000) Induction of differentiation and apoptosis by ligands of peroxisome proliferator-activated receptor gamma in non-smal cell lung cancer. Cancer Res 60: 1129-1138

Chawla A, Schwarz EJ, Dimaculangan DD, Lazar MA (1994) Peroxisome proliferator activated receptor (PPAR) gamma: adipose-predominant expression and induction early in adipocyte differentiation. Endocrinology 135: $798-800$

Demetri GD, Fletcher CD, Mueller E, Sarraf P, Naujoks R, Campbell N, Spiegelman BM, Singer S (1999) Induction of solid tumor differentiation by the peroxisome proliferator-activated receptor-gamma ligand troglitazone in patients with liposarcoma. Proc Natl Acad Sci USA 96: 3951-3956

Elnemr A, Ohta T, Iwata K, Ninomia I, Fushida S, Nishimura G, Kitagawa H, Kayahara M, Yamamoto M, Terada T, Miwa K (2000) PPAR $\gamma$ ligand (thiazolidinedione) induces growth arrest and differentiation markers of human pancreatic cancer cells. Int J Oncol 17: 1157-1164

Elstner E, Muller C, Koshizuka K, Williamson EA, Park D, Asou H, Shintaku P, Said JW, Heber D, Koeffler HP (1998) Ligands for peroxisome proliferator-activated receptor- $\gamma$ and retinoic acid receptor inhibit growth and induce apoptosis of human breast cancer cells in vitro and in BNX mice. Proc Natl Acad Sci USA 95: 8806-8811

Evans HL, Ayala AG, Romsdahl MM (1977) Prognostic factors in chondrosarcoma of bone: a clinicopathologic analysis with emphasis on histologic grading. Cancer 40: $818-831$

Göttlicher M, Heck S, Herrlich P (1998) Transcriptional cross-talk, the second mode of steroid hormone receptor action. J Mol Med 76: 480-489

Kamei Y, Xu L, Heinzel T, Torchia J, Kurokawa R, Gloss B, Lin SC, Heyman RA, Rose DW, Glass CK, Rosenfeld MG (1996) A CBP integrator complex mediates transcriptional activation and AP-1 inhibition by nuclear receptors. Cell 85: $403-414$ et al, 2000; Morrison and Farmer, 1999). Recently, Motomura et al (2000) reported that activation of PPAR $\gamma$ by troglitazone inhibited cell growth and G1 arrest through the increase of cycline dependent kinase inhibitor $\mathrm{p} 27^{\mathrm{Kip} 1}$ in human pancreatic carcinoma cells. They found that the effect of troglitazone on the proliferation of cancer cells was inhibited by antisense for p $27^{\text {Kip1 }}$. We have also found by immunohistochemistry that OUMS-27 cells express $\mathrm{p} 27^{\mathrm{Kip} 1}$ at the protein level after incubation with $15 \mathrm{~d}-\mathrm{PGJ}_{2}$ $\left(10 \mu \mathrm{g} \mathrm{ml}^{-1}\right)$ for $4 \mathrm{~h}$, but failed to show its expression by Western blot analysis (data not shown). Further cell cycle analysis on $\mathrm{p} 27^{\mathrm{Kip} 1}$ is under investigation to elucidate the mechanism of PPAR $\gamma$ ligands-induced cell growth inhibition in OUMS-27 cells.

In conclusion, the current study showed that $\operatorname{PPAR} \gamma$ activators induce apoptosis of human chondrosarcoma cells, suggesting that $\operatorname{PPAR} \gamma$ activators might have potential therapeutic benefit in the treatment of chondrosarcoma. The signal transduction pathway for the induction of apoptosis is still unclear. Whether $15 \mathrm{~d}-\mathrm{PGJ}_{2}$ can also induce tumour cell death in experimentally transplanted chondrosarcoma models remains to be examined.

\section{ACKNOWLEDGEMENTS}

The authors wish to thank $\mathrm{Mr} \mathrm{N}$ Kishimoto in the Central Research Laboratory of Okayama University Medical School for technical assistance. We also thank Mrs Cherie McCown for advice on drafting the manuscript.
Keelan JA, Sato TA, Marvin KW, Lander J, Gilmour RS, Mitchell MD (1999) 15-Deoxy-Delta(12,14)-prostaglandin J(2), a ligand for peroxisome proliferator-activated receptor-gamma, induces apoptosis in JEG3 choriocarcinoma cells. Biochem Biophys Res Commun 262: 579-585, doi: 10.1006/bbrc.1999.1257

Kitamura S, Miyazaki Y, Shinomura Y, Kondo S, Kanayama S, Matsuzawa Y (1999) Peroxisome proliferator-activated receptor gamma induces growth arrest and differentiation markers of human colon cancer cells. Jpn J Cancer Res 90: $75-80$

Kliewer SA, Umesono K, Noonan D, Heyman RA, Evans RM (1992) Convergence of 9-cis retinoic acid and peroxisome proliferator signalling pathways through heterodimer formation of their receptors. Nature 358: $771-774$

Koga H, Sakisaka S, Harada M, Takagi T, Hanada S, Taniguchi E, Kawaguchi T, Sasatomi K, Kimura R, Hashimoto O, Ueno T, Yano H, Kojiro M, Sata M (2001) Involvement of p21(WAF1/Cip1), p27(Kip1), and p18(INK4c) in troglitazone-induced cell-cycle arrest in human hepatoma cell lines. Hepatology 33: 1087-1097, doi: 10.1053/jhep.2001.4024

Kubota T, Koshizuka K, Williamson EA, Asou H, Said JW, Holden S, Miyoshi I, Koeffler HP (1998) Ligand for peroxisome proliferator-activated receptor gamma (troglitazone) has potent antitumor effect against human prostate cancer both in vitro and in vivo. Cancer Res 58: 3344-3352

Kunisada T, Miyazaki M, Mihara K, Gao C, Kawai A, Inoue H, Namba M (1998) A new human chondrosarcoma cell line (OUMS-27) that maintains chondrocytic differentiation. Int J Cancer 77: 854-859

Latruffe N, Vamecq J (2000) Evolutionary aspects of peroxisomes as cell organelles, and of genes encoding peroxisomal proteins. Biol Cell 92: 389-395

Levine AJ (1997) p53, the cellular gatekeeper for growth and division. Cell 88: $323-331$

Miyashita T, Nagao K, Krajewski S, Salvesen GS, Reed JC, Inoue T, Yamada M (1998) Investigation of glucocorticoid-induced apoptotic pathway: processing of caspase-6 but not caspase-3. Cell Death Differ 5: 1034-1041 Mirra J (1989) Intramedullary cartilage- and chondroid-producing tumors. In Bone Tumors, pp 439-690. Philadelphia: Lea and Febiger 
Morrison RF, Farmer SR (1999) Role of PPARgamma in regulating a cascade expression of cyclin-dependent kinase inhibitors, p18(INK4c) and p21(Waf1/Cip1), during adipogenesis. J Biol Chem 274: 17088-17097

Motomura W, Okumura T, Takahashi N, Obara T, Kohgo Y (2000) Activation of peroxisome proliferator-activated receptor gamma by troglitazone inhibits cell growth through the increase of $\mathrm{p} 27^{\mathrm{KiP} 1}$ in human pancreatic carcinoma cells. Cancer Res 60: $5558-5564$

Mueller E, Smith M, Sarraf P, Kroll T, Aiyer A, Kaufman DS, Oh W, Demetri G, Figg WD, Zhou XP, Eng C, Spiegelman BM, Kantoff PW (2000) Effects of ligand activation of peroxisome proliferator-activated receptor gamma in human prostate cancer. Proc Natl Acad Sci USA 97: 10990-10995

Nishida K, Doi T, Matsuo M, Ishiwari Y, Tsujigiwa H, Yoshida A, Shibahara M, Inoue H (2001) Involvement of nitric oxide in chondrocyte cell death in chondro-osteophyte formation. Osteoarthritis Cartilage 9: 232-237 doi: 10.1053/joca.2000.0380

Okura T, Nakamura M, Takata Y, Watanabe S, Kitami Y, Hiwada K (2000) Troglitazone induces apoptosis via the p53 and Gadd45 pathway in vascular smooth muscle cells. Eur J Pharmacol 407: 227-235

Ozaki T, Lindner N, Hillmann A, Todl R, Blasius S, Winkelmann W (1996) Influence of intralesional surgery on treatment outcome of chondrosarcoma. Cancer 77: 1292-1297

Sarraf P, Mueller E, Jones D, King FJ, DeAngelo D, Partridge JB, Holden SA, Chen LB, Singer S, Fletcher C, Spiegelman BM (1998) Differentiation and reversal of malignant changes in colon cancer through PPARgamma. Nat Med 4: $1046-1052$

Sato H, Ishihara S, Kawashima K, Moriyama N, Suetsugu H, Kazumori H, Okuyama T, Rumi MA, Fukuda R, Nagasue N, Kinoshita Y (2000) Expression of peroxisome proliferator-activated receptor (PPAR)gamma in gastric cancer and inhibitory effects of PPARgamma agonists. $\mathrm{Br} \mathrm{J}$ Cancer 83: $1394-1400$, doi: $10.1054 /$ bjoc. 2000.1457
Schajowics F (1994) Chondrosarcoma. In Tumors and tumor like lesions of bone, pp 201-230. Berlin: Springer

Sheth DS, Yasko AW, Johnson ME, Ayala AG, Murray JA, Romsdahl MM (1996) Chondrosarcoma of the pelvis. Prognostic factors for 67 patients treated with definitive surgery. Cancer 78: 745-750

Sheppard KA, Phelps KM, Williams AJ, Thanos D, Glass CK, Rosenfeld MG, Gerritsen ME, Collins T (1998) Nuclear integration of glucocorticoid receptor and nuclear factor- $\kappa \mathrm{B}$ signaling by CREB-binding protein and steroid receptor coactivator-1. J Biol Chem 273: 29291-29294

Takahashi N, Okumura T, Motomura W, Fujimoto Y, Kawabata I, Kohgo Y (1999) Activation of PPARgamma inhibits cell growth and induces apoptosis in human gastric cancer cells. FEBS Lett 455: 135-139

Tontonoz P, Singer S, Forman BM, Sarraf P, Fletcher JA, Fletcher CD, Brun RP, Mueller E, Altiok S, Oppenheim H, Evans RM, Spiegelman BM (1997) Terminal differentiation of human liposarcoma cells induced by ligands for peroxisome proliferator-activated receptor gamma and the retinoid X receptor. Proc Natl Acad Sci USA 94: 237-241

Tsubouchi Y, Sano H, Kawahito Y, Mukai S, Yamada R, Kohno M, Inoue K, Hla T, Kondo M (2000) Inhibition of human lung cancer cell growth by the peroxisome proliferator-activated receptor-gamma agonists through induction of apoptosis. Biochem Biophys Res Commun 270: 400-405, doi: $10.1006 /$ bbrc. 2000.2436

Unni KK (1996) Chondrosarcoma (primary, secondary, de-differentiated, and clear-cell). In Dahlin' bone tumors, pp 71-108. Philadelphia: Lippincott-Raven

Yee LD, Sabourin CL, Liu L, Li HM, Smith PJ, Seewaldt V, Kniss DA (1999) Peroxisome proliferator-activated receptor gamma activation in human breast cancer. Int J Oncol 15: $967-973$ 